\title{
INTERAKSI GURU DAN SISWA DALAM PROSES BELAJAR MENGAJAR DI SMA NEGERI 1 MEDAN PERSPEKTIF ANALISIS WACANA KRITIS van Dijk (1993)
}

\author{
Ariani br Perangin-angin ${ }^{1}$, T. Silvana Sinar ${ }^{2}$, T. Thyrhaya Zein ${ }^{3}$ \\ E-mail: ${ }^{1}$ ariani_keliat@yahoo.com, ${ }^{2}$ tengkusilvana@usu.ac.id, \\ 3.thyrhaya@usu.ac.id \\ Linguistik, Fakultas Ilmu Budaya, Universitas Sumatera Utara, Indonesia
}

\begin{abstract}
Abstrak
Penelitian ini menganalisis bentuk atau pola interaksi guru dan siswa pada level struktur mikro, struktur makro dan superstruktur, serta menganalisis konteks sosial yang merealisasikan interaksi guru dan siswa dalam proses belajar mengajar di SMA Negeri 1 Medan. Penelitian ini merupakan jenis penelitian kualitatif yang dilakukan di SMA Negeri 1 Medan. Data dalam penelitian ini adalah teks berupa unit linguistik dalam bentuk kata, frasa, klausa dan kalimat yang diperoleh dari ujaran guru yang telah di transkripsikan oleh peneliti dengan menggunakan teknik catat. peneliti menggunakan 3 metode pengumpulan data yaitu metode observasi, wawancara dan dokumentasi. Data dianalisis dengan menggunakan teknik analisis model interaktif. Hasil analisis data menunjukkan bahwa bentuk atau pola interaksi guru dan siswa pada level struktur mikro bahwa kelas kata yang paling sering digunakan oleh guru di SMA Negeri 1 Kota Medan adalah kelas kata nomina yang muncul sebanyak $38 \%$. Pada level struktur makro dalam proses belajar mengajar di SMA Negeri 1 Medan terdiri dari 7 topik, yaitu (1) greetings (salam pembuka), (2) absensi (3) mengulang pelajaran minggu lalu (4) melanjutkan pelajaran yang baru (5) Analisis topik Presentasi (6) motivasi (7) menyimpulkan materi. Sebagai referensi tambahan dan pembelajaran dalam proses peningkatan kualitas seorang guru atau pun calon guru sebagai pengajar yaitu dengan memperhatikan bagaimana interaksi yang baik dalam mengajar di dalam kelas yang dapat menciptakan suasana kondusif dan terjadinya kerja sama yang baik antara guru dengan siswa.
\end{abstract}

Kata Kunci : Interaksi guru dan siswa, Analisis Wacana Kritis

\section{PENDAHULUAN}

Interaksi belajar mengajar adalah kegiatan timbal balik antara guru dengan siswa, atau dengan kata lain bahwa interaksi belajar mengajar adalah suatu kegiatan sosial, karena antara siswa dengan temannya, antara siswa dengan gurunya ada suatu komunikasi sosial atau pergaulan. Roestilah (2014:35) mengemukakan bahwa interaksi adalah proses dua arah yang mengandung tindakan atau perbuatan komunikator maupun komunikan. Berarti interaksi dapat terjadi antar pihak jika pihak yang terlibat saling memberikan aksi dan reaksi. Sehubungan dengan itu interaksi adalah proses saling mengambil peran. 
Dalam berinteraksi di kelas, baik guru dan siswa harus mampu merespon apa yang terjadi dalam kelas. Guru tanggap tentang perilaku siswa baik dalam bertutur, siswa kadang kala diikuti gerakan atau tindakan untuk membantu proses berkomunikasi. Interaksi dalam kelas antara guru dan siswa jelas konteksnya yaitu guru menyampaikan pelajaran. Dari proses komunikasi atau pemakaian bahasa dalam interaksi antara guru dan siswa di kelas banyak kejadian yang menarik untuk diteliti. Peristiwa tutur yang terjadi pada interaksi guru dan siswa di dalam kelas adalah pemakaian bahasa baik yang bersifat interaksional ataupun bersifat transaksional. Hal ini berkaitan dengan pemakaian bahasa guru dalam menyampaikan materi pelajaran kepada siswa. Sebaliknya pemakaian bahasa siswa saat merespons guru dalam menyampaikan pelajaran. Di samping itu pemakaian bahasa interaksi siswa satu dengan siswa yang lain di dalam kelas.

Penelitian tentang interaksi guru dan siswa dalam proses belajar mengajar perlu dilakukan, karena kasus pembullyian siswa terhadap guru pada saat proses pembelajaran dan sebaliknya. Hal tersebut disebabkan kurang harmonisnya interaksi yang terjadi antara guru dan siswa yang menyebabkan siswa kurang menghormati guru dan guru kurang menyayangi siswa layaknya anak didik. Selain itu, kualitas belajar siswa di berbagai daerah di Indonesia juga sangat sulit ditingkatkan, hal tersebut juga berkaitan dengan pola interaksi guru dan siswa yang buruk sehingga menyebabkan siswa tidak menyukai mata pelajaran yang dibawakan oleh guru tertentu.

SMA Negeri 1 Medan merupakan sekolah rujukan di kota Medan yang memiliki visi dan misi 'melaksanakan pembelajaran aktif, kreatif dan menyenangkan untuk menghantarkan siswa agar berprestasi dalam IPTEK (Ilmu Pengetahuan dan Teknologi), olahraga dan seni berlandaskan Iman dan Taqwa (IMTAQ) yang siap bersaing di era globalisasi serta peduli terhadap lingkungan hidup'. Sebagai salah satu SMA rujukan di Kota Medan yang merupakan barometer SMA dikota Medan. Oleh sebab itu, SMA Negeri 1 Medan dipilih oleh peneliti menjadi lokasi penelitian dengan alasan di atas, sehingga penelitian ini nantinya dapat dijadikan sebagai bahan perbandingan dan pembelajaran bagi 
guru-guru yang mengajar di sekolah yang masih belum termasuk kategori favorit (Kemendikbud, 2018).

Untuk dapat mengetahui bagaimana SMA Negeri 1 Medan dapat menjadi sekolah rujukan yang banyak meluluskan siswa dengan prestasi gemilang, maka harus diketahui terlebih dahulu bagaimana pola interaksi yang terjadi pada saat proses belajar mengajar berlangsung. Biasanya pada saat proses belajar mengajar berlangsung, guru-guru di SMA Negeri 1 Medan menciptakan suasana belajar yang wajar, tanpa tekanan dalam kondisi yang merangsang siswa untuk belajar. Selain itu, guru-guru tersebut juga menyertakan partisipasi siswa di dalam kelas, dengan begitu guru tersebut dapat membangun komunikasi dengan siswa, mengetahui apa yang menjadi kebutuhan siswa, melatih dan menanamkan sikap demokratis siswa sehingga memberikan kreatifitas siswa untuk mampu belajar dengan potensi yang sudah mereka miliki yaitu dengan memberikan kebebasan dalam melaksanakan pembelajaran dengan cara belajarnya sendiri.

Berdasarkan fenomena di atas, yaitu pola interaksi pada proses belajar mengajar yang berlangsung di SMA Negeri 1 Medan tersebut, maka peneliti tertarik untuk mengetahui lebih dalam lagi tentang stuktur makro, superstruktur dan struktur mikro pada proses belajar mengajar di SMA Negeri 1 Medan.

Penelitian tentang pola interaksi dalam proses belajar mengajar di SMA Negeri 1 Medan dititikberatkan pada teori Analisis Wacana Kritis model van Dijk (1993) dengan alasan bahwa peneliti melihat suatu teks terdiri atas beberapa struktur atau tingkatan yang saling mendukung, yakni stuktur makro, superstruktur dan struktur mikro yang dapat membongkar sebuah ideologi yang terkandung pada sebuah teks.

Berdasarkan survey awal yang dilakukan dengan mengobservasi guru dan siswa, diketahui bahwa sebelum memulai pembelajaran, siswa SMA Negeri 1 Medan kerap menaruh perhatian terhadap guru yang akan memberikan pembelajaran, dari hal tersebut terlihat bahwa ada keinginan siswa untuk meniru guru yang disebabkan karena guru tersebut memperlihatkan atau mempunyai sifat dan kualitas yang hebat, yang berhasil, anggun, berkuasa dan sifat-sifat lain.

Guru mampu mengajar dengan baik dan membuat siswa semakin tertarik untuk mengetahui materi yang diberikan guru tersebut dan meyakinkan siswa 
untuk selalu mengulang-ulang apa yang disampaikan guru tersebut di rumah. Dalam hubungan ini guru di SMA Negeri 1 Medan memberikan teladan penerapan konteks sosial berupa pengaruh karakter kepribadian yang kuat dan berciri khas, sehingga mampu menjadi magnet bagi orang lain untuk melakukan hal yang sama. Keinginan siswa di SMA Negeri 1 Medan memperhatikan dipengaruhi oleh kebutuhan-kebutuhan dan minat-minat pribadi. Semakin ada hubungannya dengan kebutuhan dan minatnya, semakin mudah tertarik perhatiannya; sebaliknya tidak adanya kebutuhan dan minat, menyebabkan seseorang tidak tertarik perhatiannya.Berdasarkan paparan di atas, peneliti tertarik untuk menganalisis interaksi guru dan siswa dalam proses belajar mengajar di SMA Negeri 1 Medan dengan pendekatan Analisis Wacana Kritis model van Dijk (1993).

\section{RUANG LINGKUP PENELITIAN}

Penelitian ini dilakukan di SMA Negeri 1 Medan yang membahas tentang interaksi guru yang terjadi pada saat proses belajar mengajar dengan pendekatan Analisis Wacana Kritis model van Dijk (1993).

\section{TINJAUAN PUSTAKA}

Penelitian ini menggunakan teori Analisis Wacana Kritis Model Dijk (1993). Van Dijk (1993) mengintegrasikan secara bersama-sama analisis wacana yang didasarkan pada linguistik dan bahasa sebagai praktik sosial yang mengandung implikasi bahwa wacana memiliki tiga dimensi: teks, kognisi sosial dan konteks. Dalam teks (stuktur mikro) van Dijk (1993) berusaha meneliti dan memaknai bagaimana struktur teks dan strategi wacana secara kebahasaan. Pada level kognisi sosial (Superstruktur) dipelajari bagaimana proses produksi teks yang melibatkan kognisi individu.

Pada level konteks sosial (struktur makro) mempelajari struktur wacana yang berkembang dalam masyarakat. Analisis Wacana Kritis van Dijk (1993) merupakan model yang paling banyak dijadikan kajian, karena mengelaborasi elemen-elemen wacana sehingga dapat didaya gunakan dan dipakai secara praktis (Eriyanto, 2006: 221). Menurut van Dijk (1993), penelitian suatu wacana tidak cukup bila hanya didasarkan pada teks semata karena pada kenyataannya 
teks hanyalah hasil dari suatu praktik produksi yang juga harus diamati. Jadi, harus dilihat pula bagaimana suatu teks diproduksi, apakah produksi itu melibatkan suatu proses yang disebut sebagai kognisi sosial.

Berdasarkan paparan di atas peneliti menyimpulkan bahwa teori Analisis Wacana Kritis model van Dijk (1993) yang berusaha untuk menghubungkan wacana dengan konteks sosialnya sebagai elemen besar struktur sosial (stuktur makro) dan elemen wacana (struktur mikro), serta elemen kognisi sosial (superstruktur) sangat cocok digunakan sebagai pisau analisis, untuk menganalisis bagaimana bentuk atau pola interaksi guru dan siswa pada level struktur mikro, struktur makro dan superstruktur dalam proses belajar mengajar di SMA Negeri 1 Medan dan bagaimana konteks sosial yang merealisasikan interaksi guru dan siswa dalam proses belajar mengajar di SMA Negeri 1 Medan.

\section{METODE PENELITIAN}

Penelitian ini merupakan penelitian kualitatif yang menggunakan paradigma wacana kritis, yaitu untuk melakukan penafsiran terhadap interaksi guru dan siswa di SMA Negeri 1 Medan. Sedangkan metode untuk menganalisis data adalah metode deskriptif dengan perspektif Analisis Wacana Kritis. Paradigma alamiah ini mencoba menemukan dengan menganalisis data yang

diperoleh secara sistematis. Model penelitian alamiah ini mencoba menemukan data empiris dari hasil wawancara dan pengamatan atau observasi di lapangan (Denzin, 2009:32).

Adapun data yang digunakan dalam penelitian ini berupa unit linguistik dalam bentuk kata, frasa, klausa dan kalimat yang diperoleh dari ujaran guru yang telah di transkripsikan oleh peneliti dengan menggunakan teknik catat. Sedangkan sumber data dalam penelitian ini yaitu rekaman video guru dalam kegiatan belajar mengajar di SMA Negeri 1 Medan. Adapun guru yang akan diteliti adalah guru mata pelajaran Bahasa inggris kelas $\mathrm{X}$ sebanyak 2 orang guru, sedangkan siswa yang diteliti adalah siswa kelas X MIA 1 dan kelas X MIA 2. Kedua kelas tersebut merupakan kelas unggulan. Siswa di kelas tersebut sering mengikuti berbagai olimpiade, baik yang diadakan pihak sekolah, hingga olimpiade nasional.

Melengkapi penelitian ini, digunakan beberapa teknik pengumpuan data 
dengan beberapa cara, yaitu: (1) Observasi, peneliti mengamati proses belajarmengajar di SMA Negeri 1 Medan; (2) Wawancara dengan mengajukan pertanyaan langsung kepada informan atau subjek penelitian. Pada penelitian ini teknik digunakan untuk mencari serta mengumpulkan data-data tertulis yang berhubungan dengan masalah penelitian, yaitu untuk melengkapi dan mendukung keterangan dan fakta-fakta yang ada hubungannya dengan interaksi guru dan siswa. Data tersebut diperoleh melalui rekaman video

Setelah data terkumpul, maka peneliti menggunakan teknik analisis data Miles, Huberman dan Saldana (2014) yang menyatakan bahwa analisis data merupakan tahap selanjutnya setelah data terkumpul. Data yang sudah siap dan sudah dicatat dalam kartu data dan diklasifikasikan secara sistematis sesuai dengan kepentingan penelitian kemudian dianalisis. Teknik analisis data dalam penelitian ini terdiri atas empat tahapan kegiatan yang terjadi secara bersamaan yakni pengumpulan data (wawancara, observasi, dan dokumentasi), kondensasi data (memilih, memfokuskan, menyerhanakan, mengabstraksi dan mentransformasikan ), penyajian data, dan penarikan kesimpulan atau verifikasi.

\section{PEMBAHASAN}

\section{Analisis Bentuk atau Pola Interaksi Guru dan Siswa Pada Level Struktur Mikro}

Adapun bentuk atau pola interaksi guru dan siswa pada level struktur mikro dalam proses belajar mengajar di SMA Negeri 1 Medan adalah untuk melihat elemen semantik yang terdapat pada wacana interaksi yang dilakukan guru dan siswa yang sangat erat hubungannya dengan elemen leksikon sebab penggunaan leksikon tertentu dalam wacana dapat memunculkan makna tertentu. Pada dasarnya elemen ini menandakan bagaimana seseorang melakukan pemilihan kata atas berbagai kemungkinan kata yang tersedia. Pilihan kata-kata yang dipakai menunjukkan sikap dan ideologi tertentu. Adapun analisis data bentuk atau pola interaksi guru dan siswa pada level struktur mikro dalam proses belajar mengajar di SMA Negeri 1 Medan adalah sebagai berikut: 


\section{Data 1}

$\frac{\underline{w h o}}{\text { siapa }} \quad \frac{i s}{\text { yang }} \quad \frac{\underline{a b s e n}}{\text { absen }} \quad \frac{\text { todav }}{\text { hari ini }}$

Berdasarkan data 1 di atas, kalimat 'who is absen today' yang dalam padanan katanya dalam bahasa Indonesia adalah 'siapa yang absen hari ini' terdiri dari beberapa jenis kata, yaitu :

who is absen today

/pronomina/ / KKB/ /adjektiva/ /nomina/

Data 1 tersebut menunjukkan empati kepada siswa-siswinya.

\section{Data 2}

Last time we have studied English $\underline{\text { do }} \underline{\text { you }} \underline{\text { still }}$ Kemarin guru telah belajar Bahasa Inggris apakah kamu masih

remember what is our material? mengingat apa materi guru?

Berdasarkan data 2, yaitu pada kalimat 'Last time we have studied English, do you still remember what is our material?' yang dalam padanan katanya dalam Bahasa Indonesia adalah 'kemarin guru telah belajar Bhasa Inggris, apakah kamu masih mengingat apa materi guru ? terdiri dari beberapa jenis kata, yaitu:

Last time we have studied English. do

/adjektiva/ /nomina/ /pronomina/ /verba/ /adjektiva/ /Adjektiva/ /verba/

vou still rememberwhat is our

/pronomina/ adverbia/ /verba/ /pronomina/ /KKB//pronomina/

material?

/nomina/

Interaksi pada data di atas menunjukkan bahwa guru sengaja memancing siswa untuk mengingat kembali tentang materi yang telah dipelajari pada pertemuan sebelumnya. Usaha guru tersebut sebenarnya adalah untuk membuka kembali wawasan siswa tentang pelajaran yang telah dipelajari akan siswa tetap ingat pelajaran tersebut. 


\section{Data 3}

anvone of vou, who wants to ask them? seseorang dari kalian siapa ingin bertanya pada mereka

Berdasarkan data 3 di atas, kalimat 'anyone of you, who wants to ask them?' yang padanan katanya dalam bahasa Indonesia yaitu 'seseorang dari kalian siapa yang ingin bertanya pada mereka' terdiri dari beberapa kelas kata yaitu sebagai berikut :

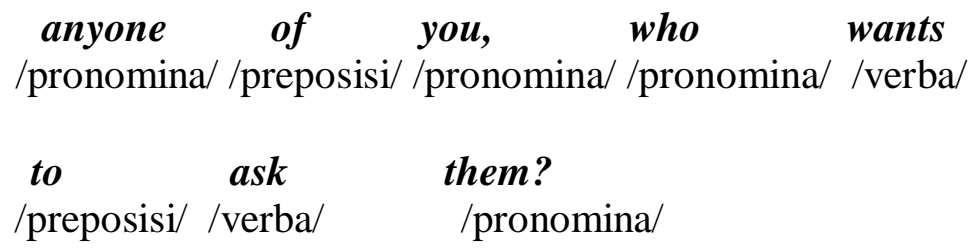

Interaksi pada data di atas menunjukkan sikap guru dan metode guru dalam membuka wawasan dan keberanian guru dalam bertanya pada saat siswa lain telah selesai memaparkan presentasi mereka.

\section{Data 4}

veah, because you have done yourbestright? yah karena kalian telah melakukan yang terbaik

Berdasarkan data 4 di atas, kalimat 'yeah, because you have done your best right?' yang padanan katanya dalam bahasa Indonesia yaitu : yah, karena kalian telah melakukan yang terbaik" . Kalimat tersebut di atas terdiri dari beberapa kelas kata, yaitu :

yea, because you have done your

/adverbia/ /konjungsi/ /pronomina/ /verba/ /adjektiva/ /pronomina/

best right?

/adjektiva/ /adjektiva/

Pada kalimat di atas telah terjadi interaksi yaitu respon positif guru kepada siswa yang telah berhasil mempresentasikan hasilnya, sehingga diketahui bahwa guru memuji usaha siswa dengan menyatakan bahwa siswa telah memberikan yang terbaik pada saat melakukan presentasi. 


\section{Data 5}

$\frac{\text { vup, }}{\text { ya }} \frac{\text { inspiring person. }}{\text { seseorang yang menginspirasi }} \frac{\text { So, }}{\text { Jadi, }} \frac{\text { after }}{\text { setelah }} \frac{\text { know }}{\text { tahu }}$

the inspiringperson, $\underline{\text { are }} \underline{\text { you }} \underline{\underline{i n s p i r e}}$ to be seseorang yang menginspirasi apakah kalian terinspirasi menjadi

like them invour reality, your own life? seperti mereka dalam kehidupan nyata anda, hidup anda sendiri

Berdasarkan data 5 di atas, kalimat yup, inspiring person So, after know the inspiring person, are you inspire to be like them in your reality, your own life?' yang padanan katanya dalam bahasa Indonesia yaitu ya seseorang yang menginspirasi. Jadi, setelah tahu seseorang yang menginspirasi apakah kalian terinspirasi menjadi seperti mereka dalam kehidupan nyata anda, hidup anda sendiri. Kalimat tersebut terdiri dari beberapa kelas kata yaitu :

yup, inspiring person

/verba/ /verba/ /nomina/

So, after know the inspiring person, /adverbia//preposisi//verba/ /artikel/ /verba/ /nomina/ are you inspire to be like them /KKB/ /pronomina/ /verba/ /preposisi/ /verba/ /adjektiva/ /pronomina/ in your reality, your own life? /preposisi//pronomina/ /nomina/ /pronomina/ /adjektiva/ /nomina/

Hasil analisis di atas menunjukkan bahwa pada saat penutupan, guru memberikan motivasi kepada siswa.

\section{Analisis Bentuk atau Pola Interaksi Guru dan Siswa Pada Level Struktur Makro}

Analisis bentuk atau pola interaksi guru dan siswa pada level struktur struktur makro dalam proses belajar mengajar di SMA Negeri 1 Medan adalah dengan menganalisis topik pada setiap frasa atau kalimat yang diucapkan oleh siswa kepada guru. Topikalisasi ialah pemilihan dan penandaan topik yaitu sesuatu yang dibicarakan. Adapun analisis bentuk atau pola interaksi guru dan 
siswa pada level struktur struktur makro dalam proses belajar mengajar di SMA Negeri 1 Medan, yaitu sebagai berikut:

Berikut ini, dipaparkan topik yang terdapat pada setiap ucapan yang disampaikan oleh Teacher (T) dan Student (S).

(1) Analisis topik greetings (salam pembuka)

\begin{tabular}{|c|c|c|c|}
\hline Data & 1 & $\mathrm{~T}$ & : morning \\
\hline Data & 2 & $\mathrm{~S}$ & : morning mam \\
\hline Data & 3 & $\mathrm{~T}$ & : how are you this morning \\
\hline Data & 4 & $\mathrm{~S}$ & : fin e mam \\
\hline Data & 5 & $\mathrm{~T}$ & $\begin{array}{l}\text { : fine? Ok good. And you Michelle, how about you? Are } \\
\text { you okay? Michelle: yes mam }\end{array}$ \\
\hline Data & 6 & $\mathrm{~T}$ & : yea, you look so fine today, and also all of your fri \\
\hline
\end{tabular}

Pada analisis topik greetings (salam pembuka) yaitu ada keterkaitan antara interaksi guru dan siswa, yaitu : Kata morning yang diulang sampai tiga kali pada kalimat yang berbeda. Kata morning pertama oleh guru digunakan untuk menyapa siswa, dan kata morning kedua juga digunakan oleh siswa sebagai balasan untuk greeting yang di sampaikan guru. Sedangkan kata morning ketiga digunakan guru untuk menanyakan kabar siswa. Penggalan interaksi tersebut dipertahankan kesinambungannya dengan cara pengulangan, yaitu topik yang terdapat pada kalimat pertama diulang pada kalimat berikutnya. Pengulangan tersebut bertujuan untuk mempertahankan kesinambungan topik dalam penggalan interaksi tersebut

Kata fine yang diulang sampai enam kali pada kalimat yang berbeda. Kata Fine pertama digunakan untuk menjawab pertanyaan guru, sedangkan kata fine kedua digunakan guru untuk berusaha meyakinkan siswa apakah mereka dalam keadaan sehat, kata good digunakan guru sebagai balasan bahwa keadaan siswa sehat, dan guru masih terus menanyakan kabar salah seorang siswanya dengan frasa 'how about you', dan mempertegasnya dengan kalimat okay, dan dibalas siswanya dengan jawaban 'yes'. Penggalan interaksi tersebut dipertahankan kesinambungannya dengan cara pengulangan, yaitu topik yang terdapat pada kalimat pertama diulang pada kalimat berikutnya.

(2) Analisis topik absensi

$\begin{array}{llll}\text { Data } & \mathbf{7} & \mathrm{T} & \text { : who is absen today } \\ \text { Data } & \mathbf{8} & \mathrm{S} & \text { : ivana and andrea mam } \\ \text { Data } & \mathbf{9} & \mathrm{T} & \text { : do you know why? }\end{array}$


Data $10 \mathrm{~S}$ : they're joining the competition mam, speech competition Data $11 \mathrm{~T}$ : oh good

Kata who yang diulang sampai tiga kali pada kalimat yang berbeda. Topik pada percakapan tersebut di atas diketahui bahwa kata who pertama berkaitan dengan kata ivana dan andrea serta berkaitan dengan kata they're. Penggalan interaksi tersebut dipertahankan kesinambungannya dengan cara pengulangan, yaitu topik yang terdapat pada kalimat pertama diulang pada kalimat berikutnya. Pengulangan tersebut bertujuan untuk mempertahankan kesinambungan topik dalam penggalan interaksi tersebut.

(3) Analisis topik apresiasi

$\begin{array}{llll}\text { Data } & 12 & \mathrm{~T} & \text { : ok very good, give big applause for them } \\ \text { Data } & 13 & \mathrm{~T} & \text { : ok, how do you feel now? } \\ \text { Data } & 14 & \mathrm{~S} & \text { : free mam... }\end{array}$

Kata presentation? yang diulang sampai dua kali pada kalimat yang berbeda. Topik pada percakapan di atas yaitu presentation dan them, keduanya saling berkaitan yaitu merekalah yang melakukan presentation. Kata you dan free adalah dua kata yang berkaitan, yaitu untuk menunjukkan bagaimana perasaan siswa yang telah lega karena telah maju presentasi. Penggalan interaksi tersebut dipertahankan kesinambungannya dengan cara pengulangan, yaitu topik yang terdapat pada kalimat pertama diulang pada kalimat berikutnya. Pengulangan tersebut bertujuan untuk mempertahankan kesinambungan topik dalam penggalan interaksi tersebut

(4) Analisis topik motivasi

$\begin{array}{llll}\text { Data } & \mathbf{1 5} & \mathrm{T} & \text { : yeah, because you have done your best right? } \\ \text { Data } & \mathbf{1 6} & \mathrm{T} & \text { : actually, what do you get from the presentation? } \\ \text { Data } & \mathbf{1 7} & \mathrm{S} & \text { : knowledge mam } \\ \text { Data } & \mathbf{1 8} & \mathrm{S} & \text { : inspiring }\end{array}$

Kata what is our material? yang diulang sampai tiga kali pada kalimat yang berbeda. Pada percakapan di atas, topik yang berkaitan adalah get, knowlegde, dan inspiring. Ketiga topik tersebut adalah tentang apa yang diperoleh oleh siswa selama presentasi dan siswa menjawab knowlegde dan inspiring. Penggalan interaksi tersebut dipertahankan kesinambungannya dengan cara pengulangan, 
yaitu topik yang terdapat pada kalimat pertama diulang pada kalimat berikutnya. Pengulangan tersebut bertujuan untuk mempertahankan kesinambungan topik dalam penggalan interaksi tersebut

\section{Analisis Bentuk atau Pola Interaksi Guru Dan Siswa Pada Level Superstruktur dalam Proses Belajar Mengajar di SMA Negeri 1 Medan}

Analisi bentuk atau pola interaksi guru dan siswa pada level superstruktur dalam proses belajar mengajar di SMA Negeri 1 Medan adalah mengorganisasikan topik dengan cara menyusun kalimat atau unit-unit beritanya berdasarkan urutan atau hiraki yang diinginkan. Teks atau wacana umumnya mempunyai skema atau alur dari pendahuluan sampai akhir. Alur tersebut menunjukkan bagaimana bagian-bagian dalam teks disusun dan diurutkan sehingga membentuk kesatuan arti. Meskipun mempunyai bentuk dan skema yang beragam, wacana umumnya mempunyai dua kategori skema besar.

Superstruktur merupakan kerangka suatu teks, seperti bagian pendahuluan, isi, penutup, dan simpulan. Sebagai teks yang utuh memiliki struktur yang dapat dianalisis secara mendetail sehingga ditemukan isi dari wacana interakasi. Analisis akan memusatkan pada skematik interakasi, yaitu bagian dan urutan interakasi diskemakan. Wacana umumnya mempunyai skema atau alur dari pendahuluan sampai akhir. Alur tersebut menunjukkan bagian-bagian dalam teks disusun dan diurutkan sehingga membentuk kesatuan arti.

\section{Analisis Pendahuluan}

Analisis pendahuluan yang dimaksud yaitu bagaimana seorang guru memulai pembelajaran di dalam kelas, apa saja kata atau kalimat yang di ucapkan oleh guru tersebut dalam melakukan interkasi.

$\begin{array}{lll}\text { Data 1 } & \mathrm{T} & \text { : morning } \\ \text { Data 2 } & \mathrm{S} & \text { : morning mam } \\ \text { Data } 3 & \mathrm{~T} & \text { : how are you this morning }\end{array}$

Analisis superstruktur pada interaksi guru dan siswa yaitu, kata morning oleh guru berkaitan dengan kata morning pada paragraf dua, dan berkaitan juga pada kata morning yang ketiga. yang artinya kata morning muncul sebanyak 3 kali. Kata morning merupakan sebuah kata untuk membuka ruang interaksi antara guru dan siswa. 


\begin{tabular}{|c|c|c|}
\hline Data 4 & S & : fine mam \\
\hline Data 5 & $\mathrm{~T}$ & $\begin{array}{l}\text { : fine? Ok good. And you Michelle, how about you? Are } \\
\text { you okay? Michelle: yes mam }\end{array}$ \\
\hline Data 6 & $\mathrm{~T}$ & : yea, you look so fine today, and also all of your friends \\
\hline
\end{tabular}

Analisis superstruktur pada interaksi guru dan siswa yaitu, kata fine oleh siswa berkaitan dengan kata ok good pada paragraf dua, dan berkaitan juga pada kata look yang ketiga yang artinya muncul sebanyak 3 kali. Kata fine merupakan sebuah kata untuk menyampaikan kabar antara guru dan siswa.
Data 7 T : who is absen today
Data 8 S : ivana and andrea mam
Data $9 \quad \mathrm{~T} \quad$ : do you know why?
Data $10 \quad \mathrm{~S}$ : they're joining the competition mam, speech competition
Data $11 \quad \mathrm{~T}$ : oh good

Analisis superstruktur pada interaksi guru dan siswa yaitu, kata who oleh guru berkaitan dengan kata ivana dan andrea pada paragraf dua, dan berkaitan juga pada kata you know why dan juga berkaitan dengan kata 'good' oleh guru yang ketiga yang artinya muncul sebanyak 4 kali. Kata fine merupakan sebuah kata untuk menyampaikan kabar antara guru dan siswa.

\section{Analisis Pembukaan}

Analisis pembukaan yang dimaksud yaitu bagaimana seorang guru memancing siswa agar tertarik terhadap pelajaran yang akan diberikan di dalam kelas, apa saja kata atau kalimat yang di ucapkan oleh guru tersebut dalam melakukan interkasi. Berikut merupakan analisis pembukaan

Data 12 T: last time we have studied English, do you still remember what is

Data 13 S : biography

Data 14 T : about what?

Data $15 \mathrm{~S}$ : biography mam.

Data $16 \mathrm{~T}$ : ok, good. Do you still remember what is biography?

Data $17 \quad \mathrm{~S}$ : to retell about someone past experience

Data 18 T: yeah .. good..

Data $19 \mathrm{~T}$ : ok, now, the time for the presentation

Data $20 \mathrm{~T}$ : anyone of you, who wants to ask them?

Analisis superstruktur pada interaksi guru dan siswa yaitu, kata what is our material oleh guru berkaitan dengan kata biography pada paragraf dua, dan 
berkaitan juga pada kata you still remember what is biography dan juga berkaitan dengan kata 'to retell about someone past experience' oleh siswa yang artinya muncul sebanyak 5 kali. Kata fine merupakan sebuah kata untuk menyampaikan kabar antara guru dan siswa.

Data 21

Data 22

Data 23
S: ok very good, give big applause for them

$\mathrm{T}$ : ok, how do you feel now?

$\mathrm{S}:$ free $\operatorname{mam} . .$.

Analisis superstruktur pada interaksi guru dan siswa yaitu, kata ok very good oleh guru berkaitan dengan kata how do you feel pada paragraf dua, dan berkaitan juga pada kata free oleh siswa yang artinya muncul sebanyak 3 kali. Kata ok very good merupakan sebuah kata untuk menyampaikan kabar antara guru dan siswa.

\section{Analisis Penutupan}

Analisis penutupan yang dimaksud yaitu bagaimana seorang guru mengahiri pembelajaran di dalam kelas, apa saja kata atau kalimat yang di ucapkan oleh guru tersebut dalam berinterkasi, oleh sebab itu data berikut akan menjelaskan bagaimana guru menutup pembelajaran.

\begin{tabular}{|c|c|c|}
\hline Data 24 & $\mathrm{~T}$ & : yeah, because you have done your best right? \\
\hline Data 25 & $\mathrm{~T}$ & : actually, what do you get from the presentation? \\
\hline Data 26 & $\mathrm{~S}$ & : knowledge mam \\
\hline Data 27 & $\mathrm{~S}$ & : inspiring \\
\hline Data 28 & $\mathrm{~T}$ & $\begin{array}{l}\text { yup, inspiring person. So, after know the inspiring } \\
\text { person, are you inspire to be like them in your } \\
\text { reality, your own life? }\end{array}$ \\
\hline
\end{tabular}

Analisis superstruktur pada interaksi guru dan siswa yaitu, kata because you have done your best right oleh guru berkaitan dengan kata what do you get from the presentation pada paragraf dua, dan berkaitan juga pada kata knowledge oleh siswa yang artinya muncul sebanyak 3 kali. Kata inspiring merupakan sebuah kata untuk menyampaikan kabar antara guru dan siswa.

\section{KESIMPULAN}

Paparan data di atas menyimpulkan bahwa Berdasarkan hasil analisis yang dilakukan oleh peneliti pada kegiatan pembelajaran di SMA N 1 Kota Medan, maka penelitian ini dapat disimpulkan sebagai berikut: Bentuk atau pola interaksi 
guru dan siswa pada level struktur makro, struktur mikro dan superstruktur dalam proses belajar mengajar di SMA Negeri 1 Medan. yaitu: Peneliti menemukan bahwa bentuk atau pola interaksi guru dan siswa pada level struktur mikro bahwa kelas kata yang paling sering digunakan oleh guru di SMA Negeri 1 Kota Medan adalah kelas kata nomina yang muncul sebanyak $38 \%$. pada level struktur makro dalam proses belajar mengajar di SMA Negeri 1 Medan terdiri dari 7 topik, yaitu (1) greetings (salam pembuka), (2) absensi (3) mengulang pelajaran minggu lalu (4) melanjutkan pelajaran yang baru (5) Analisis topik Presentasi (6) motivasi (7) menyimpulkan materi. Pada lever superstruktur ditemukan pola interaksi berupa pendahuluan, pembukaan dan penutup.

\section{DAFTAR PUSTAKA}

Denzin, N. K dan Lincoln, Y. 2009. Handbook of Qualitative Research: 591- 632. Diterjemahkan oleh Dariyatno. Terbitan ke-1. Yogyakarta: Pustaka Pelajar

Dijk, Teun A.Van. Ed. 1985. Handbook of Discourse Analisis: Discourse Analisys in society. London: Academic Press, Inc.

Eriyanto. 2006. Pengantar Analisis Wacana. Pengantar Analisis Teks Media. Yogyakarta: Lkis

https://psma.kemdikbud.go.id/index/

Miles, Metthew B, A. Michael Huberman and Johnny Saldana. 2014. Qualitative Data Analysis, A Methods Sourcebook, Third Edition. Sage Publications, Inc.

Roestilah. 2014. Strategi Belajar Mengajar. Rineka Cipta: Jakarta 